\title{
Where Soutine Started His Journey
}

Jolanta Šrkaité

Lithuanian Culture Research Institute, Saltoniškių 58, Vilnius, 08105

Email: sirkaite@gmail.com

\begin{abstract}
The article presents the first years of Chaïm Soutine, the remarkable artist of the Ecole de Paris. The reconstruction of the facts of his life in Smilavichy and the years of art education in Minsk and Vilnius is based on the bibliography about the artist and the recollections of the artists who were close to Soutine in his youth. KEYWORDS: Chaïm Soutine, Schraga Faibich Zarfin, Michel Kikoïne, Smilavichy, Minsk, Yakov Krieger's Drawing School, Vilnius Drawing School, Ivan Trutnev, Ivan Rybakov
\end{abstract}

Chaim Soutine is undoubtedly one of the most remarkable artists of the last century, and, alongside, the most mysterious one. He did not leave any memoirs and did not like talking about himself or his family. Soutine's creative career has been the subject of numerous publications - books, articles, even works of fiction, ${ }^{1}$ and memoirs of his contemporaries. Besides reliable facts, many of these publications include a considerable number of legends that are often repeated from publication to publication.

Soutine's real date of birth is unknown to this day. Neither is it known when 13 January appeared in his biography. Even though it is commemorated by many of the artist's fans, this date is not confirmed by any authentic document. Soutine could not remember even the year of his birth. He indicated 1893 to the Paris prefecture, but when asked by his friends about his date of birth, he could only say that he was born in 1894. In his article, Marc Restellini quotes the correspondence between Albert Barnes and Pierre Loeb of $1936^{2}$ in which the former asked the latter to inquire about Soutine's date of birth for the book that he was preparing. Loeb gave the following answer: "Soutine himself is not sure about the real date of his birth. He remembers being born in 1894 but doesn't know more precise details". ${ }^{3}$ However, the year 1893 is commonly considered the year of his birth, as indicated in the earliest Paris document pertaining to Soutine - a certificate produced by the Russian embassy on the basis of which Soutine's French identity document was issued.

1 Dutli 2017.

2 Restellini 2007: 9-10.

3 Ibidem. 
Michel LeBrun Franzaroli, the most authoritative contemporary researcher on Soutine, claims that he managed to find a document of 1942 in the Archives de la Préfecture de Police de Paris indicating that Soutine was born in May $1893 .{ }^{4}$

Whatever the case with the date of birth is, there are numerous other gaps in the early period of the artist's life as an ordinary Jewish boy in Belarus and an ordinary Jewish adolescent in Vilnius, Lithuania. From 1795, these two territories of the former Grand Duchy of Lithuania were part of the Russian Empire.

The document mentioned above contains another mistake: "Smirlovitch" is indicated as his birthplace. It was most likely written down by ear as high-ranking Russian officials had never heard of such a town.

The aim of this article is to summarise the early years of Soutine's life and to assemble them from loose memories and research related to the institutions the artist had attended.

\section{Smilavichy}

In fact, Soutine was born in Smilavichy, a remote town in the periphery of Belarus on the fringes of the Russian Empire of that time, at a distance of approximately 30 kilometres from Minsk; a town that the artist refused to remember when he lived in France. Referring to Chagall, Ralph Dutli vividly describes the atmosphere of Smilavichy, which holds true for other similar towns of present Belarus (but not Lithuania, as indicated by Waldemar-George ${ }^{5}$ ):

Smilavichy is tar. As long as I can remember, tar had always been distilled there. Childhood is the shtetl, collapsing decayed cabins, ramshackle boardwalks, stifling dust and gurgling mud, depending on the season. Coughing children and hunger. A grey town, a murky hole of a town has remained in memory. The sky is cloudy, covered with grey mist".

Recalling similar Belarusian towns, Marc Chagall would declare: "Colours there are like those of the shoes of its residents. Because of this colour, we all fled from there. ${ }^{6}$

This is what Smilavichy looked like in 1893: there were two Eastern Orthodox churches with schools, a Catholic church, a mosque, five Jewish prayer houses, two public schools, a post office and a telegraph, a textile factory, several tanneries, 58 small shops, nine inns, and two hotels. On holidays and Sundays, fairs were held in the market square; several dry goods stores, as well as a brewery and a distillery were close by. ${ }^{7}$ There was also a manor with a nicely maintained park built by the Moniuszko family in the late nineteenth century.

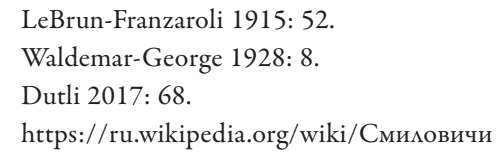


The artist Schraga Faibich Zarfin, six years Soutine's junior, who was born and raised in the same town, also gave an account of Soutine's childhood in Smilavichy. In 1958, he wrote down his memories at the request of Waldemar George. George published the abridged first part of these memoirs in the magazine Art \& Style. ${ }^{8}$ Somewhat later, they were translated into Russian and Belarusian and published in Minsk.

The population of Smilavichy was multi-ethnic: there were Jews, Poles, Russians, and Tatars, but Jews constituted the majority. According to Zarfin, there were well-off craftsmen and shop owners among them, and some of them were quite well educated. Zarfin's father, who was a tanner, subscribed to several newspapers, read Turgenev and Tolstoy, while his wife baked pies for Shabbat.

According to Zarfin, Zalman and Sara Sutin lived in a small wooden house.

It stood with its façade facing the town's main square in which markets used to take place twice or thrice a week. From its rear façade, the land plot that belonged to the Sutins extended towards the Volma River, which would flood their garden in spring. A road to the left of the house led to Minsk, and on the right, one of the town's three synagogues proudly stood. ${ }^{10}$

The Tatar community lived beyond the river.

Sutins' house has not survived, and the town itself has undergone big changes: the square has been built over, and the synagogues have not survived either. Judging from the description given by Zarfin, Sutins's house stood on the approaches to today's Chyrvonaarmeyskaya Street). Looking at the map and trying to identify the location of the house, it becomes obvious that it could not have been situated very close to the river, so the garden must have been quite large.

Zarfin recalls that Chaim's father Zalman Sutin, "a tailor of a low stature and pleasant appearance, grew up in a very religious family. After the prayers in the synagogue he would go to Zarfin's house together with his friends for a glass of liqueur and a piece of cake". ${ }^{11}$ They liked discussing the texts of the Bible and the Torah with the host, and Zarfin's father introduced him to Russian literature.

Soutin's first biographical sketches contain descriptions of his extremely poor childhood and disagreements with his parents. ${ }^{12}$ These subjective descriptions are not always true to reality and sometimes look rather exaggerated. Zarfin, and later Kikoïne, disproved some highly negative engrained statements about Soutine's childhood and family.

8 Waldemar-George 1959: 52.

9 Абаурахманаў 2013: 3; Абдурахманов 2013: 32; Абдурахманов 2020.

10 Абаурахманов 2020: 13.

11 Ibidem.

12 Waldemar-Georg 1928: 7-9; Szittya 1955: 13-14. 
Even though the family was large, the Sutins were not very poor. It was proved in the article by another Belarusian researcher Nadezhda Usova. ${ }^{13}$ Zarfin writes:

In his childhood, Soutine loved sauntering around the market together with peasants, running around the fields, or spending hours sitting on the riverbank. [...] Already as children, we both drew - he would cover the walls of his house with drawings, and I would draw in my father's account books. Chaim drew portraits, and I drew fire fighters [...]. Soutine liked to copy photographs and made their enlarged copies, whose similarity to the original fascinated the village people. ${ }^{14}$

Unfortunately, not everything went so smoothly with drawing. The majority of the town's population were Orthodox Jews, and such artistic occupations as drawing portraits ran contrary to their traditions. Here we can recall the legend about a knife stolen by the seven-year-old Chaim: he sold it to buy paint and was punished by being locked in a pantry for two days. ${ }^{15}$ One can believe that he was punished for theft rather than for buying paint.

Zarfin debunked George's statement about Soutine's father being an ignorant fanatic ("obscure et fanatique"). ${ }^{16} \mathrm{He}$ recalls that even though the father did not like his artistic inclination, "he hardly ever punished him for that, though he wouldn't miss an opportunity to express his disapproval". ${ }^{17}$ That was at the very beginning, and later, when Soutine already studied at the drawing school, "he would speak about him with his clients with pride and show them his son's drawings hanging on the walls".

\section{Minsk}

When Chaim turned ten or, more precisely, in September 1903, his father sent him to Minsk, where his married sister Cile lived. Her husband was a highly qualified tailor, so the family expected the son to learn the trade by helping him. Young Sutin had different ideas, though. Seeing his son's obsession with drawing, his father allowed him to work as a retoucher with a local photographer. Studying faces in the photographs must have helped him later in drawing portraits.

Yet it was not enough for Chaim. In 1907, he discovered Yakov Krieger's drawing school. He was learning to draw while continuing to work with the photographer. Although small, it was Soutine's first step towards professionalism. In some French sources this school is called Krieger's art academy, but it would be giving it too much credit.

\footnotetext{
13 Усова 2015, 3/1: 123-137.

14 Абаурахманов 2020: 16.

15 Augias 2006: 227.

16 Waldemar-George 1928: 8.

17 Абаурахманов 2020: 13.

18 Ibidem.
} 


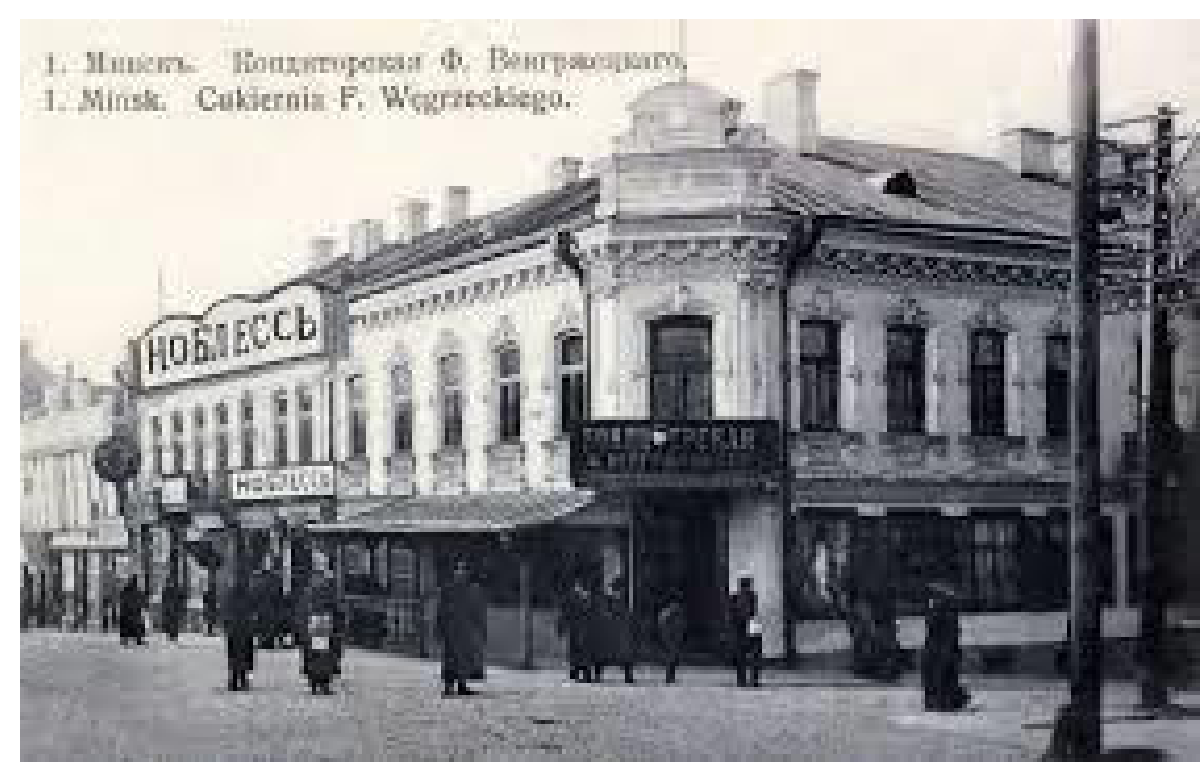

Fig. 1. Artist Krieger's Drawing School in Minsk, at 24 Petropavlovskaya Street. Postcard

The painter Yakov (Yankel) Krieger ${ }^{19}$ was born in 1869 into the family of the craftsman Morduch Krieger in Minsk. He studied at the Kiev Art School, later in Warsaw, then at the Académie Julian in Paris and, finally, at the Saint Petersburg Academy of Arts. In 1900, he returned to Minsk and in 1904 he started giving drawing classes, which became "Artist Krieger's Drawing School” in 1906. The school was located in the private two-storey house of the confectionary merchant Franciszek Węgrzecki, at 24 Petropavlovskaya Street, and occupied three rooms of that building (Fig. 1).

Krieger's first students were teachers of drawing at public schools and talented peasants from the surrounding villages. Several poorest students were exempt from the tuition fee. It is very likely that Chaim was among them. There is no mention of any other teachers of that school. Its listed alumni did not leave conspicuous traces in the history of art, with the exception of Soutine and Mikhail Kikoin, who attended the school from 1906. Krieger's school operated until 1914, when its head fled to the depths of Russia at the outbreak of the war.

It is not known how much Chaim learned at that school, but it was already a great thing that there he made friends with Misha Kikoin, who at that time was not Michel Kikoïne, but Mikhail, the son of a rich bank employee. Chaim was no longer alone and gained more courage to dream bigger. And his dream was quite close, in Vilnius, or Vilna as the Russians called it at the time, 180 kilometres away. While it was not a problem for the banker's son Kikoin, Chaim had a streak of luck. 
There exist different accounts of the development that follows. According to some, the sons of the Smilavichy rabbi, whose portrait Chaim was drawing, became enraged, beat him with sticks, and when Chaim's parents complained, the perpetrators had to pay a fine and there was enough money for him to go to Vilnius. According to other accounts, the rabbi sought to avoid the complaint and himself paid for his trip to Vilnius. Zarfin has different memories of this situation:

As he was drawing a portrait of the eighty-five-year-old man, the latter's children came running and chased Soutine away, beating him with sticks. Soutine filed a complaint about having been beaten and injured. The lay magistrate, a learned man of German origin, ruled that the wrongdoers should pay a fine of fifteen roubles. Soutine was head over heels with excitement: now he could buy the necessary materials and rent a room, as in our town he was renting a space that he used as a studio. ${ }^{20}$

It is thus quite likely that Chaim travelled to Vilnius not with the rabbi's money, and the incident described might have taken place somewhat later, when he was already studying in Vilnius.

Michel Kikoïne's son Yankel maintained that Chaim decided to go to Vilnius all by himself. He knew a dentist from Smilavichy who had his practice in Vilnius, and it was him who directed Chaim to the Vilnius Drawing School. ${ }^{21}$

\section{Vilnius}

So, it is Vilnius and the Vilnius Drawing School, also called "the Vilnius Art School" and sometimes even "Vilnius Academy" (Acádemie de Vilna) in French historiography, although not many are familiar with it.

Vilnius, the former capital of the Grand Duchy of Lithuania, which was part of the Polish-Lithuanian Commonwealth with the Kingdom of Poland, became the largest cultural centre of the so-called North-western Krai, a region of the Russian Empire after the Third Partition of the state in 1797. From as early as the fifteenth century, it was home to one of the oldest universities in Europe, the art departments of which operated from the late eighteenth century.

Unfortunately, after the first uprising against the tsarist authorities, in 1832, the university was closed and large numbers of educated people emigrated. After the second uprising of 1863-1864, many were deported to the depths of Russia. Great efforts were taken to prove that these lands had been Russian from time immemorial. The press in Latin characters was banned and only Russian-speaking teachers were allowed to teach in schools and gymnasiums. Many Catholic churches were closed or converted into Eastern Orthodox. The latter needed 
icons, and hence, loyal artists to paint them. This gave rise to an idea to found a school of drawing and crafts in Vilnius under the auspices of the Russian Ministry of Education.

The school was opened in December 1866, in the building of the closed university (Fig. 2). The Russian artist Ivan Trutnev, an alumnus of the Saint Petersburg Academy of Arts, who soon was conferred the title of academician, was invited to Vilnius to head it (Fig. 3). ${ }^{22}$ It should be noted that under his management emphasis was placed on classical academic teaching of art and icon painters were not trained there.

Gradually, the school became so popular that it attracted candidates from the surrounding governorates. Before the introduction of the Pale of Settlement, Vilnius remained open to Jews and everyone interested could attend the school regardless of their nationality, sex, or social status. The school had separate classes for male and female students. After the restructuring of the school in 1893 (the teaching of crafts was separated) and with support from the Saint Petersburg Academy of Arts, the teaching of art was improved and new fouryear curricula were designed. Ivan Rybakov, a young teacher, started teaching there in 1899 and acquainted his students with new trends in European art.

The first three years of study were open to all applicants, but the "special" course taught during the fourth year could be accessed only upon completing the initial courses or passing an examination. Judging from the fact that, having arrived in Vilnius in the summer of 1909 , Soutine took this exam, he must have enrolled in the "special" course.

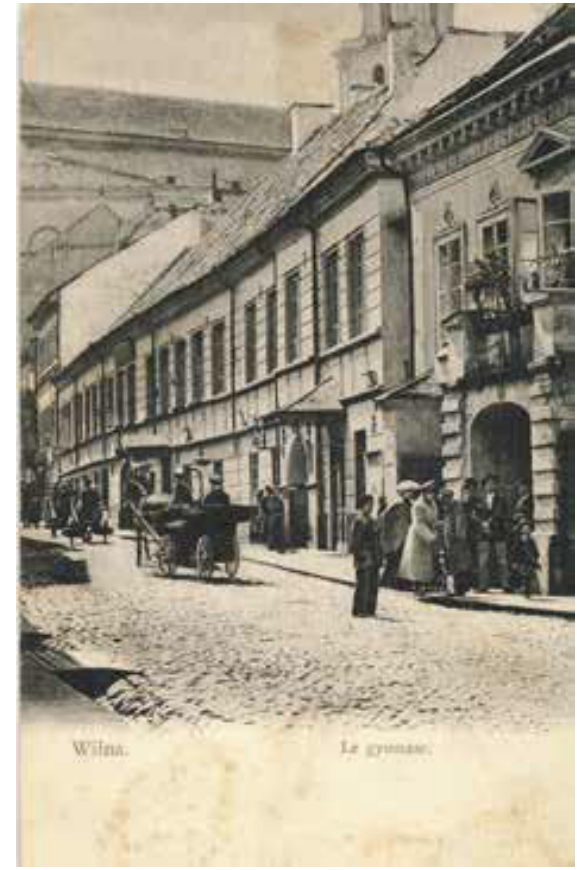

Fig. 2. Entrance to the Vilnius Drawing School from Pilies Street. Postcard

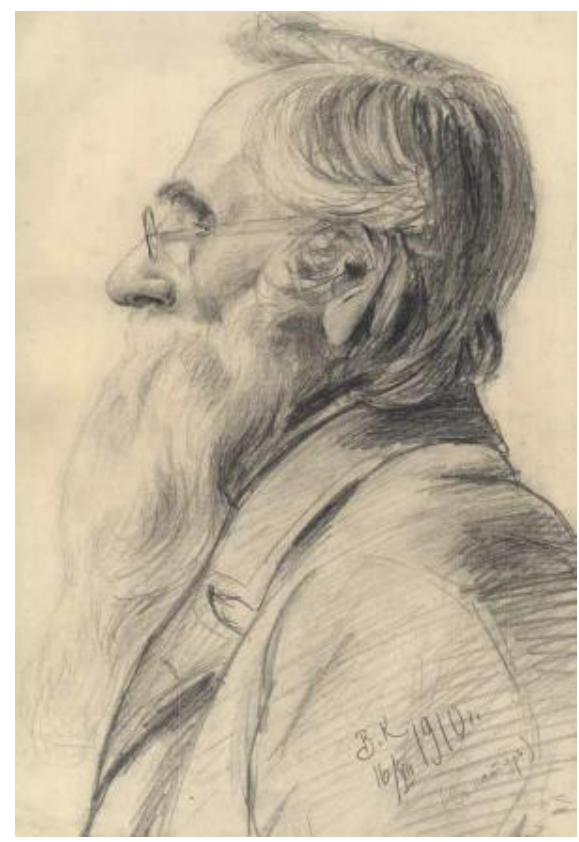

Fig. 3. Vytautas Kairiūkštis. Portrait of Ivan Trutnev, 1910. The Lithuanian National Art Museum 
Soutine did not pass the examination the first time. He arrived late and failed it out of excitement. Besides, it is unclear how much he had learned at Kruger's school. In Vilnius, students aspiring to advanced art studies had to complete a three-year course, which started from drawing simple gypsum ornaments and geometrical figures in the first year, drawing gypsum animals, parts of the human body and heads, and painting still lifes in oil in the second year, and drawing gypsum figures and half-figure sitters in the third year.

Soutine was given a special drawing lesson and allowed to retake the examination: he had to draw a combined setup of geometrical figures. A similar setup is captured in one of Trutnev's caricatures (Fig. 4).

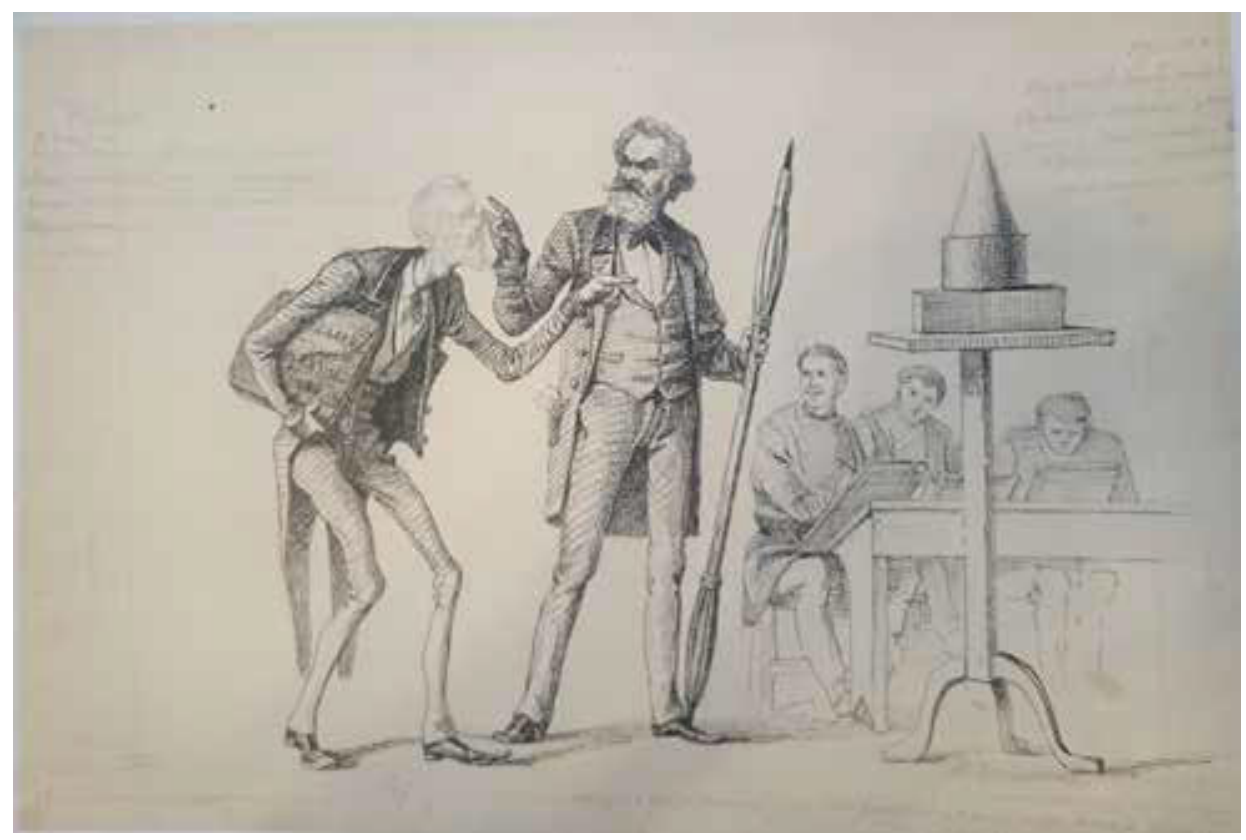

Fig. 4. Ivan Trutnev. Cartoon Inspector. The Leo Tolstoy State Museum, Moscow

At the Vilnius Drawing School, Soutine learned not only drawing, but also painting, the basics of sculpture (modelling from clay and wax), printmaking (engraving and lithography), draughtsmanship, and painting on fabric, wood, and porcelain. Theoretical subjects were also taught: linear and shadow perspective, anatomy, and the history of art. Besides, free drawing and copying of paintings was obligatory. Soutine did not abandon this part of studies in Paris either: he used to copy the works of the masters in the Louvre. The duration of study in this class was not limited, thus Soutine attended it for three years. He took this class together with Misha Kikoin and also made friends with Pinchus Kremen (in France - Krémègne), who had arrived from Belarus earlier. 
In Vladas Didžiokas's drawing of 1911 or 1912 , we see an old man with a stick (Fig. 5). Trutnev was 83 at the time. In the centre, there is a caricature image of his assistant Ivan Rybakov, who taught Soutine and other students. Having freshly graduated from the Saint Petersburg Academy of Arts, in 1899 he started to work at the Vilnius Drawing School. It was Rybakov who familiarised the future artists with new artistic trends and encouraged the talented students to go to Paris.

The school's annual tuition fee was five roubles, but by a decision of the teachers' council students from poor families did not have to pay. It is quite likely that Soutine was among them. Zarfin maintains that as his father could not cover his living costs, he earned his living in Vilnius by drawing portraits from photographs.

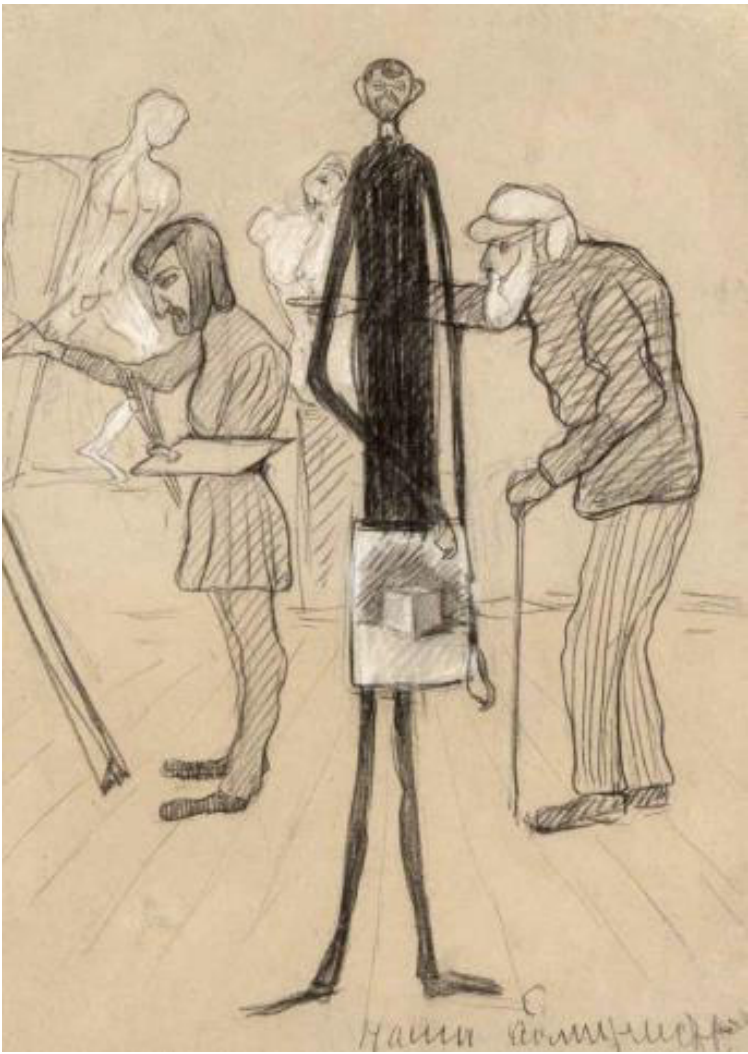

Fig. 5. Vladas Didžiokas. Our administrators, a cartoon of the teachers of the Vilnius Drawing School, 1911-1912. The Lithuanian National Museum of Art

In Vilnius, Soutine and Misha

Kikoin rented a room together with five other students and paid fifteen kopecks for the bed. ${ }^{23}$ Their limping landlady always kept a hot samovar ${ }^{24}$ ready, and the good doctor Rafelkess would invite poor students for a Shabbat dinner on Friday nights. ${ }^{25}$

There exist only two known photographs of the alumni of the Vilnius Drawing School dated 1912. We see Zarfin standing on the right in the first photo (Fig. 6) and sitting on the floor in the centre in the second, and Kikoine, with glasses, is on the left. Soutine also studied there that year, but for some reason he is not in either of the photographs. 


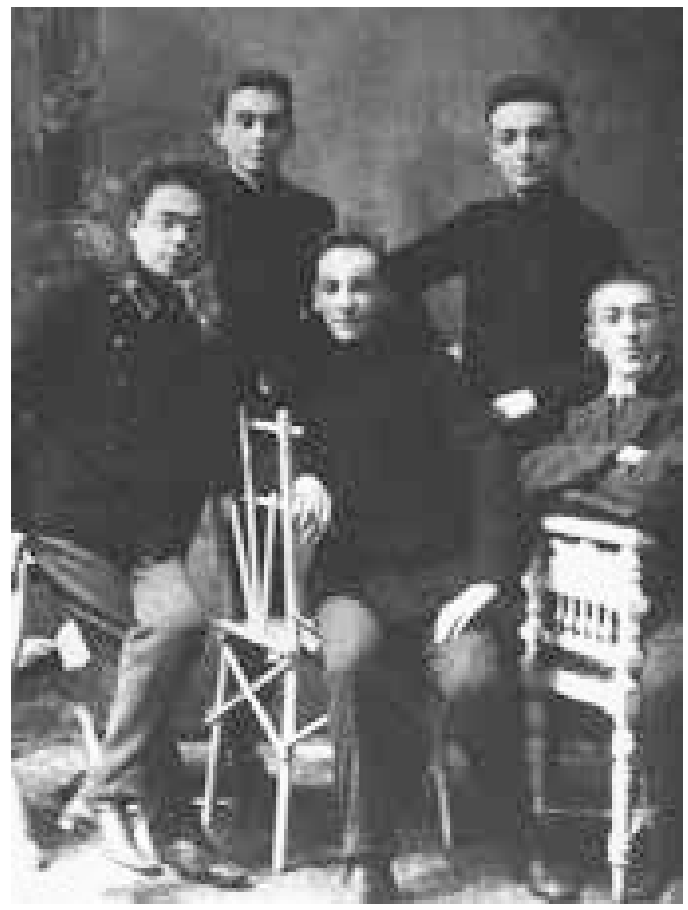

Fig. 6. Alumni of the Vilnius Drawing School. 1912. First from the left - Michel Kikoïne, right - S. F. Zarfin. Personal archive of Liliane Dulac-Zarfin
In the photograph, the alumni of the Vilnius Drawing School are wearing the school's uniform that Soutine boasted about. Zarfin recalls:

Like many other students, he would return home for Christmas and summer holidays. During summers, he used to work in the fields or at the riverbank, trying to find a place in the shade of some storehouse. Most often he looked for sitters among old men. The latter were not very keen to sit for him, so Chaim cheated. As a student of the Vilnius Drawing School, he wore the school uniform, which impressed some of the town's residents. Chaim had an idea to introduce himself as an official representative of the authorities. "The pristav [police commissar $-J . \check{S}$.] sent me to paint your portrait," he would say to old peasants. ${ }^{26}$

Another one of Zarfin's memories should be quoted: "As a young man, he took great care of his appearance and took great care of his appearance and wore his student uniform with pride. Despite his humble financial situation, he was
a dandy and wore perfume". It is quite contrary to the image of a sloppy and stinking Soutine as he was remembered by some Parisians and disliked by Zborowski's wife. Zarfin speaks of Soutin's yet another passion. According to him, not only did Soutine read Gorky, but he also played music. According to Zarfin, Soutine not only read Gorky, but also played music.

Chaim adored music. He played the balalaika, and mimicked energetically while playing. He would sing and play with abandonment, wriggling his entire body. He almost always played the same tune, claiming that it was called The Madman's Waltz. Now I think that it was the opening beats of Beethoven's Moonlight Sonata. ${ }^{27}$

It was not by accident that the first place that he visited in Paris was the Opera. When Trutnev died in February 1912, Rybakov was forced to resign a month later. Officials accused him of decadent moods and of exerting a bad influence on the students. ${ }^{28}$ Some students left the school together with their favourite teacher, though later many of them returned. It is not known if the inseparable 
trio of Soutine, Kikoïne and Krémègne was among them. The latter two left for Paris in the same year.

There is no information about what Soutin was doing for an entire year as he had no money for the journey. It was not until March 1913 that the above-mentioned benefactor, doctor Rafelkess, supported him with fifty roubles, which meant he could to go to Berlin and join his friends in Paris in June. ${ }^{29}$ He never saw his parents again and never returned to Smilavichy. He chose to cut all ties with his birthplace and his relatives. In Paris, he did not consider himself either a Jew or a Russian, as his documents said. According to Paulette Jourdain, he claimed to be a Lithuanian, although he never was one. ${ }^{30}$ Probably it was because Vilnius, being so incomparably different from Smilavichy and even from Minsk, liberated him and showed him a possibility of a different life. Vilnius was Soutine's "window to Europe" through which he could see new horizons. Vilnius was his "doorway to paradise". ${ }^{31}$

Received 10 April 2020 Accepted 28 April 2020

\section{Bibliography}

1. Augias, C. Il viaggiatore alato. La vita breve e ribell di Amedeo Modigliani. Arnoldo Mondadori Editore S. p. A., 1998.

2. Cogniat, R. Soutine. Paris: Edition du Chene, 1945.

3. Dutli, R. Paskutine Sutino kelioné. Vilnius: Sofoklis, 2017.

4. Kiköne. Les pioniers de L'École de Paris. Éditions de l'Albaron, Présence du Livre, 1992.

5. LeBrun-Franzaroli, M. Soutine photographié. Concremiers: ed. M. LeBrun-Franzaroli, 2018.

6. LeBrun-Franzaroli, M. Soutine. L'homme et le peinter... Concremiers: ed. M. LeBrun-Franzaroli, 2015.

7. Naked Soul: Chaim Soutine and Israeli Art. Ed. Y. Shapira. Ein Harod: Mishkan Museum of Art, 2019.

8. Restellini, M. Soutine, Le Fou de Smilovitchi. Soutine. Ed. M. Restellini. Paris: Pinacothèque de Paris, 2007.

9. Szittya, E. Soutine et son temps. Paris: La Bibliothèque des Arts, 1955.

10. Širkaitè, J. Vilniaus piešimo mokykla 1866-1915. Vilnius: Lietuvos kultūros tyrimų institutas, 2018.

11. Waldemar-George. Grandeur et servitude de Chaïm Soutine. Art \& Style. 1959: 52.

12. Waldemar-George. Soutine. Paris: Le Triangle, 1928.

13. Абдурахманаў, Ю. Невядомае пра Суціна. Культура: итотьцнёвая грамадска-асветніцкая газета. 2013: 3 (1077); Мишпоха. 2013: 32.

14. Усова, Н. Хаим Сутин и его семья. Sovijus. 2015. 3/1: 123-137.

15. Абаурахманов, Ю. Файбиш Шрага Царфин о Сутине, о Смиловичах, о себе. Минск: «Научный мир», 2020 .

16. Якаў Кругер. Аўтар тэксту і складальнік Н. М. Усава. Мінск: «Беларусь». 2013.

\footnotetext{
29 Cogniat 1945: 17.

30 LeBrun-Franzaroli 2015: 29.

31 Ibidem: 33.
} 
Jolanta Širkaite

\section{Kur Soutine'as pradèjo savo kelią}

\section{Santrauka}

Straipsnyje, pasitelkiant gausią literatūrą apie dailininką bei naujausius jo biografijos tyrimus, mėginama nušviesti ankstyvuosius jo gyvenimo Baltarusijoje bei Vilniuje metus, paneigti kai kuriuos stereotipinius, iš leidinio ị leidinị keliaujančius biografijos faktus. Soutine’as nepaliko jokių prisiminimų, apie save kalbẻdavo nenoriai, dažnai pats painiodavo savo gimimo datą, kuri įvairiuose šaltiniuose pateikiama nevienodai. Remiantis Soutine’o tyrinėtojo Michelio LeBrun-Franzarollio surastais dokumentais, patikslinama dailininko gimimo data. Ankstyvieji Soutine'o gyvenimo metai Smilavičiuose, jo tėvų ir namų aprašymas, visiško skurdo paneigimas pateikti remiantis jo amžininko dailininko Faibisho Schragos Zarfino prisiminimais, kurių visas tekstas neseniai publikuotas Minske. Plačiau aptarta Jakovo Kriegerio piešimo mokykla, kurioje keletą mėnesių dailès mokèsi Soutine'as, jo mokymasis Vilniaus piešimo mokykloje. Dailininko gyvenimo Vilniuje faktai ir jo pomėgiai rekonstruoti remiantis Zarfino ir kito bendražygio, Michelio Kikö̈ne’o, prisiminimais. RAKTAŽODŽIAI: Chaïmas Soutine'as, Schraga Faibichas Zarfinas, Michelis Kikoïne’as, Smilavičiai, Minskas, Jakovo Kiegerio piešimo mokykla, Vilniaus piešimo mokykla, Ivanas Trutnevas, Ivanas Rybakovas 